\title{
垂直管上昇環状流における液膜界面積濃度の軸方向発達*
}

\author{
波津久達也*1, 日引俊*2 \\ 賞 雅 寛 而*1, Mamoru ISHII*3

\section{Axial Development of Interfacial Area Concentration of Liquid Film in Vertical Upward Annular Two-phase Flow} \\ Tatsuya HAZUKU*4, Takashi HIBIKI, \\ Tomoji TAKAMASA and Mamoru ISHII \\ ${ }^{* 4}$ Faculty of Marine Technology, Tokyo University of Marine Science and Technology, \\ Etchujima, Koto-ku, Tokyo, 135-8533 Japan

\begin{abstract}
Accurate measurements of annular flow parameters such as local liquid film thickness, onedimensional interfacial area concentration of liquid film, and local interfacial area concentration profile of liquid film were performed by a laser focus displacement meter at 21 axial locations in vertical upward annular two-phase flow using a 3-m-long and 11-mm-diameter pipe. The axial distances from the inlet $(z)$ normalized by the pipe diameter $(D)$ varied over $z / D=50$ to 250 . Data were collected for preset gas and liquid flow conditions and for Reynolds numbers ranging from $\operatorname{Re}_{g}$ $=31800$ to 98300 for the gas phase and $R e_{f}=1050$ to 9430 for the liquid phase. Axial development of the one-dimensional interfacial area concentration and the local interfacial area concentration profile of liquid film were discussed with the data obtained in the experiment. Total interfacial area concentration including liquid film and droplets was also discussed with regarding to the exinting drift-flux model, entrainment correlation, and droplet size correlation.
\end{abstract}

Key Words : Multi-Phase Flow, Flow Measurements, Laser-Aided Diagnostics, Interfacial Area Transport Equation, Interfacial Area Concentration, Annular Two-Phase Flow, Liquid Film, Droplet

\section{1. はじめに}

様々な工学分野における二相流解析手法として一般 的な二流体モデルがその真価を発揮するには，二相の 相互作用の強さを表す界面輸送項（=界面積濃度×駆 動力）の適切なモデル化が必要となる. 現在, 界面輸 送項は，定常完全発達流れに対する流動様式遷移基準 に基づき, 流動様式毎に構成式の形で与えられている ため, 時空間スケールを考慮した界面構造の変動特性 を模擬できないことが問題点として指摘されている. このような状況を打開する手段として，二流体モデル への界面積濃度輸送方程式の導入が提案されている(1). この導入により入口効果や流れの発達, 壁面沸騰等が 界面積濃度輸送に及ぼす効果を系統的に表現すること が可能となり，二流体モデルを用いた流れ解析におけ る界面輸送項の定式化の飛躍的な進歩が期待されてい る. 現在, 界面積濃度輸送方程式の開発に関する解析 的, 実験的研究が精力的に行われており, 特に気泡流

* 原稿受付 2005 年 7 月 13 日.

*1 正員, 東京海洋大学海洋工学部 -135 -8533 東京都江東区 越中島).

*2 正員, 京都大学原子炉実験所 ( - 590-0494 大阪府泉南郡熊 取町朝代西).

*3 Purdue University (West Lafayette, IN 47907-2017, USA).

E-mail : hazuku@e.kaiyodai.ac.jp
からスラグ流域を対象にしたモデル化は, 近年目覚し い進展を遂げている(2へ。．しかしながら，界面積濃度 輸送方程式の確立には, より広範な流路環境と流動条 件を対象にした現象のモデル化と，それを検証するた めの精度の高い局所流れ場のデータベースの構築が必 要となる. 特に, 沸騰伝熱様式で大半占める環状流領 域は, 他の流動様式と比較して熱伝達率が高く, また 液膜のドライアウトに起因した伝熱管損傷をもたらす 流動条件への遷移過程にあるため, その流動特性を詳 細に捉え, 液膜および夜滴の界面積濃度の生成, 消滅 項に関するモデル化を図っていくことが, 機器の設計 と安全性評価において極めて重要となる. しかしなが ら, 環状流の界面積濃度輸送に関する研究は, その物 理メカニズムに対する理解の不十分さと計測の困難さ から, 遅々として進展していない状況にある.

本研究では, 環状流域を対象にした界面積濃度輸送 方程式の開発を最終目的とし, その第一段階として, 垂直管上昇環状流における液膜の一次元平均界面積濃 度と管断面界面積濃度分布の管軸方向発達特性を実験 的に整理する. また，既存のドリフトフラックスモデ ルのおよび液滴径と液滴飛散量に関する相関式(8)(9)を用 いた環状流界面積濃度の評価方法を検討し, 液膜界面 積濃度の計測結果との比較からその適用性を評価する 
とともに, 環状流の全界面積濃度に対する液膜界面積 濃度の寄与率を評価する.

\section{おもな記号}

\begin{tabular}{|c|c|}
\hline$A$ & : 面積 \\
\hline$a_{\mathrm{i}}$ & : 界面積濃度 \\
\hline$a_{\text {idop }}$ & : 液滴の界面積濃度 \\
\hline$z_{i}$ fim & : 液膜の界面積濃度 \\
\hline$a_{i \text { ival }}$ & : 全界面積濃度 \\
\hline$\tilde{i}_{\text {ifilm }}$ & $:$ 無次元液膜界面積濃度 $=a_{\mathrm{i} \text { 价 }} \Delta x$ \\
\hline$C_{\mathrm{m}}$ & : 液膜界面積増加係数 \\
\hline & : 管内径 \\
\hline E & : 液滴流量比 \\
\hline$E_{\mathrm{d}}$ & : 全液相面積に対する液滴の面積比 \\
\hline$E_{\infty}$ & : 準平衡状態における液滴流量比 \\
\hline$g$ & : 重力加速度 \\
\hline$j$ & : 全体積流束 \\
\hline$j_{\text {ore }}$ & : 気相流部の全体積流束 \\
\hline$j_{\mathrm{d}}$ & : 液滴体積流束 \\
\hline$j_{\mathrm{f}}$ & : 液相見かけ速度 \\
\hline$j_{\mathrm{g}}$ & $:$ 気相見かけ速度 \\
\hline$N_{\mu f}$ & : 無次元粘性数 $=\mu_{\mathrm{f}} /\left[\rho_{\mathrm{f}} \sigma(\sigma / g \Delta \rho)^{05}\right]^{05}$ \\
\hline $\operatorname{Re}$ & : レイノルズ数 $=j D / v$ \\
\hline$r_{\mathrm{d}}$ & : 液滴半径 \\
\hline$r_{\mathrm{vm}}$ & : 液滴の体積平均半径 \\
\hline$r_{\mathrm{Sm}}$ & : 液滴のザウター平均半径 \\
\hline & : 速度 \\
\hline$V_{\mathrm{g}}$ & : 気相ドリフト速度 \\
\hline$W e$ & : ウェーバー数 $=\left(\Delta \rho / \rho_{\mathrm{g}}\right)^{1 / 3} \rho_{\mathrm{g}} j_{\mathrm{g}}^{2} D / \sigma$ \\
\hline & : ボイド率 \\
\hline$\alpha_{\text {ore }}$ & : 気相流部の断面積比 \\
\hline$\alpha_{d}$ & : 気相流部における液滴の断面積比 \\
\hline & : 液膜厚さ \\
\hline$\Gamma$ & : 単位濡れ長さ当りの液相体積流量 \\
\hline & : 粘性係数 \\
\hline & : 動粘性係数 \\
\hline & : 密度 \\
\hline & : 気液の密度差 \\
\hline & : 表面張力 \\
\hline
\end{tabular}

添穴字

$$
\begin{array}{ll}
\text { d : 液滴 } \\
\mathrm{f} \text { : 液相 } \\
\mathrm{ff} & \text { : 液膜 } \\
\mathrm{g} & \text { : 気相 }
\end{array}
$$

数学記号
- : 時間平均值
\langle\rangle : 面積平均値
《》: ボイド率加重平均値

$\mathrm{m}^{2}$

$\mathrm{m}^{-1}$

$\mathrm{m}^{-1}$

$\mathrm{m}^{-1}$

$\mathrm{m}^{-1}$

$-$

$-$

$\mathrm{m}$

$-$

$-$

$-$

$\mathrm{m} / \mathrm{s}^{2}$

$\mathrm{m} / \mathrm{s}$

$\mathrm{m} / \mathrm{s}$

$\mathrm{m} / \mathrm{s}$

$\mathrm{m} / \mathrm{s}$

$\mathrm{m} / \mathrm{s}$

$-$

$-$

m

$\mathrm{m}$

m

$\mathrm{m} / \mathrm{s}$

$\mathrm{m} / \mathrm{s}$

$-$

$-$

$-$

$-$

$\mathrm{m}$

$\mathrm{m}^{3} / \mathrm{s} / \mathrm{m}$

$\mathrm{Pa} \cdot \mathrm{s}$

$\mathrm{m}^{2} / \mathrm{s}$

$\mathrm{kg} / \mathrm{m}^{3}$

$\mathrm{kg} / \mathrm{m}^{3}$

$\mathrm{N} / \mathrm{m}$

\section{2. 環状流における界面输送モデルの予借検付}

2. 1 環状流の界面稍清度 環状流の管断面平均 界面積濃度を次式で与える.

$$
\left\langle a_{\mathrm{i}}\right\rangle=\left\langle a_{\mathrm{i} \text {.film }}\right\rangle+\left\langle a_{\mathrm{i} \text {.drop }}\right\rangle=\frac{4 C_{\text {an }}}{D} \sqrt{\frac{\langle\alpha\rangle}{1-\alpha_{\mathrm{d}}}}+\frac{\langle\alpha\rangle}{1-\alpha_{\mathrm{d}}}\left(\frac{3 \alpha_{\mathrm{d}}}{r_{\mathrm{sm}}}\right)
$$

右辺第一項と第二項はそれぞれ液膜と液滴の平均界面 積濃度を示している， $\alpha, r_{\mathrm{Sm}}$ はそれぞれボイド率, 液 滴のザウター平均半径であり, $\alpha_{\mathrm{d}}$ は次式で定義され る気相流部の液滴面積比である.

$$
\alpha_{\mathrm{d}}=\frac{A_{\mathrm{d}}}{A-A_{\mathrm{ff}}}=\frac{(1-\langle\alpha\rangle) E_{\mathrm{d}}}{1-(1-\langle\alpha\rangle)\left(1-E_{\mathrm{d}}\right)}
$$

ここで, $A_{\mathrm{d}}$ と $A_{\mathrm{ff}}$ および $E_{\mathrm{d}}$ は，それぞれ管断面におけ る夜滴と液膜の面積および液相の全面積に対する飛散 液滴の面積比 $\left[E_{\mathrm{d}} \equiv A_{\mathrm{d}} /\left(A_{\mathrm{ut}}+A_{\mathrm{d}}\right)\right]$ である. また, 式(1)

の $C_{\mathrm{an}}$ は, 液膜界面の波動による液膜界面積濃度の増 加係数である. 本研究では管周方向に均質な液膜を仮 定して $C_{\mathrm{an}}=1$ とする.

式(1)より, 環状流の管断面平均界面積濃度は， $\alpha$, $\alpha_{\mathrm{d}}$ および $r_{\mathrm{Sm}}$ を適切に与えることにより予測できる. 本研究では, これらの值を 2.2 項に示すドリフトフラ ックスモデルおよび 2.3 項に示す液滴飛散量と液滴径 に関する相関式によりそれぞれ評価する.

$2 \cdot 2$ 㻴状流のドリフトフラックスモテル＼cjkstart環状 流の平均ボイド率を, 既存のドリフトフラックスモデ ルを用いて評価する.

一次元ドリフトフラックスモデルより次式が与えら れる.

$$
\left\langle\left\langle v_{\varepsilon}\right\rangle\right\rangle=\frac{\left\langle j_{z}\right\rangle}{\langle\alpha\rangle}=\langle j\rangle+\overline{V_{\mathrm{z} j}}
$$

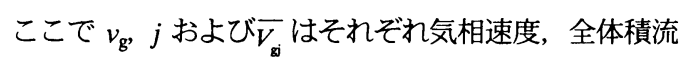
束, 気相平均ドリフト速度である. Ishii は, 液滴が発 生しない純環状流に対し, 気相平均ドリフト速度を次 式で与えている(゙.

$$
\overline{V_{\mathrm{g}}} \simeq \frac{1-\langle\alpha\rangle}{\langle\alpha\rangle+\left\{\frac{1+75(1-\langle\alpha\rangle)}{\sqrt{\langle\alpha\rangle}} \frac{\rho_{\mathrm{g}}}{\rho_{\mathrm{f}}}\right\}^{1 / 2}}\left(\langle j\rangle+\sqrt{\frac{\Delta \rho g D(1-\langle\alpha\rangle)}{0.015 \rho_{\mathrm{f}}}}\right)
$$

一方, 液滴が発生する条件での気相平均ドリフト速 度を, 式(4)の相関式と液滴流のドリフト速度相関式( を組み合わせることで, 以下のように導出する. 
気相流部の管断面積比 $\alpha_{\mathrm{our}}$ を次式で定義する.

$\alpha_{\text {core }}=\frac{A-A_{\mathrm{HH}}}{A}=\langle\alpha\rangle+E_{\mathrm{d}}(1-\langle\alpha\rangle)$

また, 気相流部における液滴の面積比 $\alpha_{\mathrm{d}}$ を用いると, $\alpha_{\text {oore }}$ は次式となる.

$\alpha_{\text {cort }}=\frac{\langle\alpha\rangle}{1-\alpha_{\mathrm{d}}}$

液膜と気相の相間速度は, 上記の $\alpha_{\text {ore }}$ を式(4)の環状 流に対する相関式の平均ボイド率の項に適用すること で得られ, 次式で表せる.

$$
\begin{aligned}
& j_{\text {core }}-\langle j\rangle \simeq \frac{1-\alpha_{\text {core }}}{\alpha_{\text {core }}+\left\{\frac{1+75\left(1-\alpha_{\text {cort }}\right)}{\sqrt{\alpha_{\text {core }}} \frac{\rho_{g}}{\rho_{\mathrm{f}}}}\right\}^{1 / 2}} \\
& \times\left[\langle j\rangle+\sqrt{\frac{\Delta \rho g D\left(1-\alpha_{\text {core }}\right)}{0.015 \rho_{\mathrm{f}}}}\right]
\end{aligned}
$$

ここで, $j$ は管断面全体積流束, $j_{\mathrm{owr}}$ は気相流部におけ る全体積流束であり, 気相流速 $v_{g}$, 液滴流速 $v_{\mathrm{d}}$, 液膜 流速 $v_{\mathrm{ff}}$ を用いてそれぞれ次式で与えられる.

$$
\begin{aligned}
& \langle j\rangle=\left[v_{\mathrm{g}}\left(1-\alpha_{\mathrm{d}}\right)+\alpha_{\mathrm{d}} v_{\mathrm{d}}\right] \alpha_{\text {cort }}+v_{\mathrm{ff}}\left(1-\alpha_{\text {core }}\right) \\
& j_{\text {cort }}=v_{\mathrm{g}}\left(1-\alpha_{\mathrm{d}}\right)+\alpha_{\mathrm{d}} v_{\mathrm{d}}
\end{aligned}
$$

一方, 気相流部の平均ドリフト速度は, 液膜より発 生する球状液滴の運動量を考慮して得られた次式で与 えられる(11).

$\left\langle\left\langle v_{\mathrm{g}}\right\rangle\right\rangle-j_{\text {core }}=0.5 r_{\mathrm{d}}\left[\frac{(g \Delta \rho)^{2}}{\mu_{\mathrm{g}} \rho_{\mathrm{g}}}\right]^{1 / 3} \alpha_{\mathrm{d}}\left(1-\alpha_{\mathrm{d}}\right)^{1.5}$

ここで， $r_{\mathrm{d}}$ は, 液滴の粒子半径である. 上式は, 以下 の液滴発生基準のを満たす場合に適用される.

$|\langle j\rangle|>1.456\left(\frac{\sigma g \Delta \rho}{\rho_{g}^{2}}\right)^{1 / 4}\left[\frac{\mu_{g}^{2}}{\rho_{g} \sigma \sqrt{\sigma / g \Delta \rho}}\right]^{-1 / 12}$

また, 液膜レイノルズ数が $R e_{\mathrm{ff}}<1635$ となる条件では, 式(11)は以下の液滴発生基準(10)を満たす場合に適用さ れる.

$$
\left\{\begin{array}{l}
\frac{\mu_{\mathrm{f}}\left\langle j_{\mathrm{g}}\right\rangle}{\sigma} \sqrt{\frac{\rho_{\mathrm{g}}}{\rho_{\mathrm{f}}}} \geq 11.78 N_{\mu \mathrm{f}}^{0.8} R e_{\mathrm{ft}}^{-1 / 3} \text { for } N_{\mu \mathrm{f}} \leq \frac{1}{15} \\
\frac{\mu_{\mathrm{f}}\left\langle j_{\mathrm{g}}\right\rangle}{\sigma} \sqrt{\frac{\rho_{\mathrm{g}}}{\rho_{\mathrm{f}}}} \geq 1.35 R e_{\mathrm{ft}}^{-1 / 3} \text { for } N_{\mu \mathrm{ft}}>\frac{1}{15}
\end{array}\right.
$$

ここで夜膜レイノルズ数 $R_{\mathrm{ff}}$ は次式で定義される.

$$
R e_{\mathrm{ft}} \equiv \frac{4 \rho_{\mathrm{f}}\left\langle\left\langle v_{\mathrm{ft}}\right\rangle\right\rangle \delta}{\mu_{\mathrm{f}}}=\frac{4 \Gamma}{v_{\mathrm{f}}}=\frac{\left\langle j_{\mathrm{t}}\right\rangle D}{v_{\mathrm{f}}}
$$

$\delta$ と $\Gamma$ は，それぞれ液膜厚さと単位濡れ長さ当りの液 相体積流量である.

以上の結果を整理すると, 液滴が発生する条件での 気相平均ドリフト速度は次式となる.

$$
\begin{aligned}
& \overline{V_{\mathrm{gj}}}=\frac{1-\alpha_{\text {core }}}{\alpha_{\text {core }}+\left\{\frac{1+75\left(1-\alpha_{\text {corc }}\right)}{\sqrt{\alpha_{\text {core }}}} \frac{\rho_{\mathrm{g}}}{\rho_{\mathrm{f}}}\right\}^{1 / 2}}\left[\langle j\rangle+\sqrt{\frac{\Delta \rho g D\left(1-\alpha_{\text {core }}\right)}{0.015 \rho_{\mathrm{f}}}}\right] \\
& +\frac{r_{\mathrm{d}}}{2}\left[\frac{(g \Delta \rho)^{2}}{\mu_{\mathrm{g}} \rho_{\mathrm{g}}}\right]^{1 / 3} \alpha_{\mathrm{d}}\left(1-\alpha_{\mathrm{d}}\right)^{1.5}
\end{aligned}
$$

ここで, 右辺第二項は, 式(11)もしくは式(12)を満足 する場合にのみ適用される. 一方, 両式を満たさない 場合, すなわち液滴が発生しない条件での気相平均ド リフト速度は, 式(4)で与えられる.

\section{3 環状流における液滴径と液滴体稍流束比}

式(1)と式(14)に示されるように, 環状流の界面積濃 度の予測には, $r_{\mathrm{d}}, r_{\mathrm{Sm}}$ および $\alpha_{\mathrm{d}}$ の評価が重要となる.

環状流における液滴の大きさと液滴径分布は, Kataoka ら(8)によって詳細に検討されている. それに従 うと, 式(14)の $r_{\mathrm{d}}$ と式(1)の $r_{\mathrm{Sm}}$ は, 概略以下の式で与 えることができる.

$r_{\mathrm{d}} \simeq r_{\mathrm{vm}}=0.005 \frac{\sigma}{\rho_{\mathrm{g}} j_{\mathrm{g}}^{2}} R e_{\mathrm{g}}^{2 / 3}\left(\frac{\rho_{\mathrm{g}}}{\rho_{\mathrm{f}}}\right)^{-1 / 3}\left(\frac{\mu_{\mathrm{g}}}{\mu_{\mathrm{f}}}\right)^{2 / 3}$

$r_{\mathrm{sm}}=0.796 r_{\mathrm{vm}}$

一方， $\alpha_{\mathrm{d}}$ は液滴飛散量の相関式により評価するこ とができる，環状流は，気相速度が大きく，また気相 流中の液滴の径が小さいことから, 液滴と気相の相間 相対速度を無視できるとし， $\alpha_{\mathrm{d}}$ を次式で近似する(14).

$\alpha_{\mathrm{d}} \simeq E j_{\mathrm{f}} / j_{\mathrm{g}}$

ここで, $E$ は液滴の体積流束比であり, 液滴の体積流 束 $j_{\mathrm{d}}$ を用いて， $E \equiv j_{\mathrm{d}} / j_{\mathrm{f}}$ で定義される. 本研究では, 管軸方向に沿った液滴の体積流束比 $E$ の変化を, 以 下の Ishii - Mishima の相関式(9)で与える.

$E=\left\{1-\exp \left(-1.87 \times 10^{-5} \varsigma^{2}\right)\right\} E_{\infty}$

ここで,

$E_{\infty}=\tanh \left(7.25 \times 10^{-7} W e^{1.25} R e_{f}^{0.25}\right)$

$\zeta=(z / D) R e_{\mathrm{f}}^{0.5} / W e^{0.25}$

また, ウェーバー数Weは次式で定義される. 
$W e \equiv \frac{\rho_{\mathrm{g}} j_{\mathrm{g}}^{2} D}{\sigma}\left(\frac{\Delta \rho}{\rho_{\mathrm{g}}}\right)^{1 / 3}$

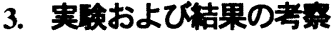

3・1 实跌禁置およひ方法 実験で使用した二相 流ループおよび実験条件は，前報(15, 10) と同様である. 計測部は長さが $3 \mathrm{~m}$ ，内径 $D=11 \mathrm{~mm}$ のアクリル管で あり，作動流体は空気と水である. 水はタンク内で温 度 $25 \pm 0.5{ }^{\circ} \mathrm{C}$, 電気伝導度 $1 \mu \mathrm{S} / \mathrm{cm}$ 以下に調整される. タンクから気液混合部に流入した水は，燒結金属管を 通過して管内面に一様な液膜となり，空気と共に計測 部を上昇する.

気液の流量条件は, 気相レイノルズ数 $R e_{\mathrm{g}}=31800$ 98300, 液相レイノルズ数 $R_{\mathrm{f}}=1050-9430$ であり, 気 液混合部からの距離 $z=550-2750 \mathrm{~mm}(z / D=50-250)$ の範囲において, 軸方向 21 箇所の液膜厚さを, レ一 ザーフォーカス変位計 ${ }^{(17,18)}$ （Laser Focus Displacement Meter: LFD, キーエンス社製 LT8100）により計測する.

$3 \cdot 2$ 一次元界面棈湿度 環状流における一次元 界面積濃度の管軸方向発達特性を評価する，液膜の一 次元界面積濃度 $\left\langle a_{i, \text { filim }}\right\rangle$ は, 平均液膜厚さ $\bar{\delta}$ を用いて 次式で表せる.

$\left\langle a_{i, \text { film }}\right\rangle=\frac{\Sigma a_{i, \text { film }}}{\Sigma t}=\frac{4}{D}\left(1-\frac{2 \bar{\delta}}{D}\right)$

各計測位置において，LFDにより計測された液膜厚 さを式(22)に代入して，液膜の一次元界面積濃度の管 軸方向変化を整理し, 前章で検討した環状流の界面積 濃度評価方法による予測結果と比較する．なお，LFD は，管壁と作動流体が透明であれば，各媒体を通過す るレーザー光の光路を理論的に予測することで, 液膜 厚さを正確に計測できる．筆者らは，これまでの研究 により，透明円管内壁面に形成する液膜の厚さを計測 する場合の屈折による誤差の補正式を与えており，管 内径 $D=10-30 \mathrm{~mm}$, 液膜厚さ $\delta=2.4 \mathrm{~mm}$ 以内の計測に 対し液膜厚さを $1 \%$ 以内の誤差範囲内で計測できるこ とを確認している

図 1 は, 助走距離に対する液膜界面積濃度の実測値 と予測結果の代表例である. 図中のプロットと線は, それぞれ実測值と予測值を示している. また，液膜界 面積濃度の軸方向変化をより明確に示すため, $z / D=$ 50 における值を基準とした液膜界面積濃度の軸方向 変化率 $\xi\left(\equiv\left\langle a_{\mathrm{i} \text {.fim }}\right\rangle /\left\langle a_{\mathrm{i} \text {,film, }, 2 \mathrm{D} D=50}\right\rangle\right)$ を図 2 に示す.これら の図からわかるように，液膜の界面積濃度は，管軸方
向の発達に伴って徐々に増加する. その増加率は, 高 い夜相レイノルズ数においてより高くなる傾向を示し， 本実験の流量条件と助走距離の範囲において最大で $3 \%$ あ゙った. 式(11)と式(12)より液滴飛散の開始条件 を評価すると，本実験のほとんど全ての気液流量条件 で液滴が発生することになる。したがって，式(1)か らわかるように, 液滴の飛散は, 液膜界面積濃度の生 成に寄与することから，管軸方向の液膜界面積濃度の 増加は, 主として液滴飛散量の増加に起因していると 言える. また, 液相レイノルズ数の増加に伴って, 液 膜界面積濃度の増加率が上昇するのは, 圧力損失と界 面せん断力が増加することで，管軸方向に沿ったボイ ド率と液滴飛散量が増加するためである，一方，液膜 界面積濃度の管軸方向変化は，前章で述べた評価方法 により良く再現できており，本実験の範囲において， 予測值と実測值の偏差は $2.5 \%$ 以内であった.

環状流域はボイド率が高く $(a=0.8-1.0)$, かつ $a_{\mathrm{d}} \ll 1$ であることから, 式(1)の右辺第一項において

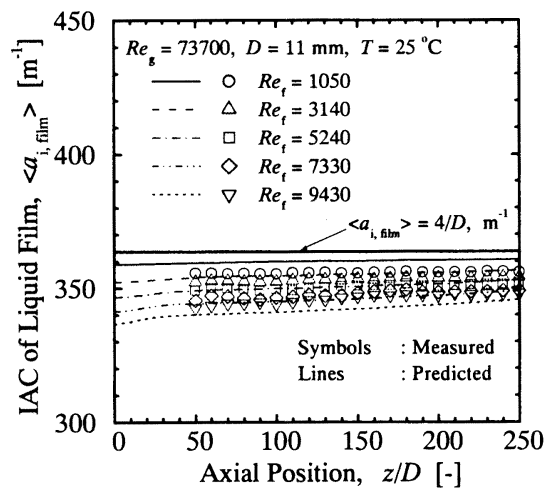

Fig. 1 Axial change of one-dimensional IAC of liquid film $\left(R e_{\mathrm{g}}=73700\right)$

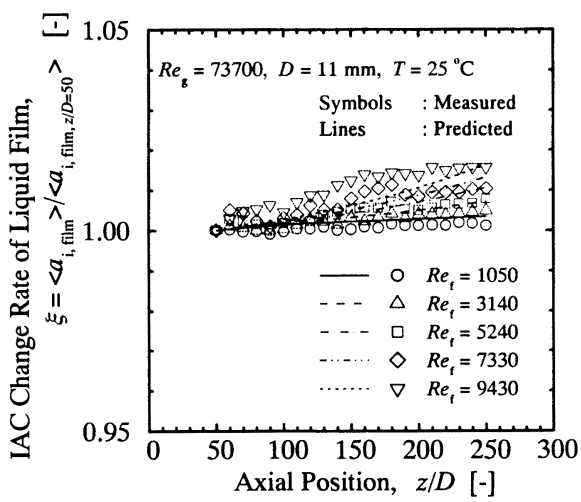

Fig. 2 Rate of one-dimensional interfacial area concentration change $\left(R e_{\mathrm{g}}=73700\right)$ 
$C_{\mathrm{an}} \sqrt{\langle\alpha\rangle /\left(1-\alpha_{\mathrm{d}}\right)} \simeq 1$ を仮定し, 液膜の界面積濃度を 4/D で与える場合がある. この仮定に基づくと，本実 験に用いたテスト管における界面積濃度は, 図 1 の太 実線で示す值, すなわち $364 \mathrm{~m}^{-1}$ となる. この值と本 実験における計測值との差は最大で $7.7 \%$ \%あり, 上 記の仮定は許容し得ると考えられる. しかしながら, 特に液膜界面挙動に強く影響を受けるドライアウトに 起因した限界熱流束の予測においては, より精度の高 いドリフトフラックスモデルや界面輸送方程式を開発 していくことが必要である.

図 3 と図 4 に, $z / D=250$ の位置における液膜界面積 濃度の気液レイノルズ数への依存性を示す．液膜界面 積濃度に与える気相レイノルズ数の影響は, 液相レイ ノルズ数が高いほどより顕著に現れている. また, 液 膜界面積濃度は, 気相レイノルズ数の増加に伴って増 加し, 液相レイノルズ数に対しては隇少する傾向を示 している. これは, 気相レイノルズ数が増加すると,

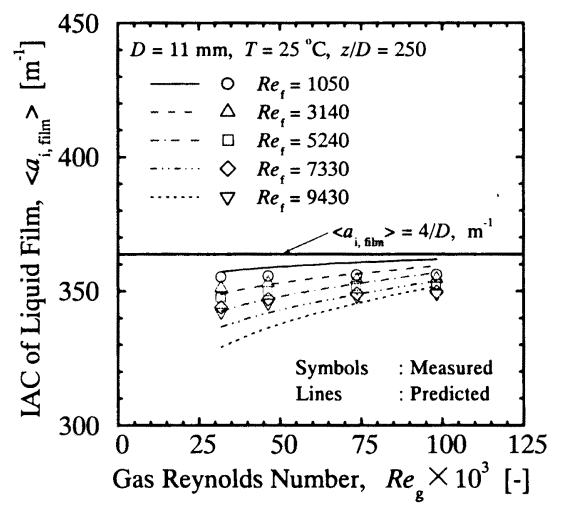

Fig. 3 Effect of gas Reynolds number on onedimensional IAC of liquid film

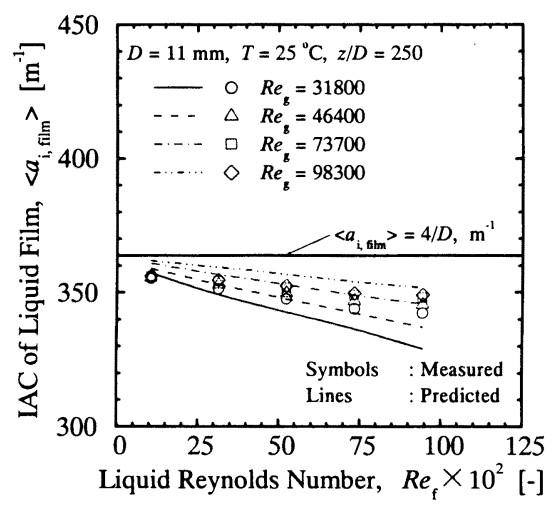

Fig. 4 Effect of liquid Reynolds number on onedimensional IAC of liquid film
液膜界面せん断力が増加して液膜厚さが減少し, また 液滴の飛散量が増加するためである. 本実験の範囲に おいて, 予測值は界面積濃度の気液レイノルズ数への 依存性を良く再現できており, 実測值との偏差は 25\%以内であった.

図 5 に, 助走距離に対する界面積濃度の実測值と予 測結果の代表例を示す. 図中のプロットと太線はそれ ぞれ液膜界面積濃度の計測值と予測值を, 細線は液滴 界面積濃度を含む全界面積濃度の予測值を示している。 全界面積濃度は, 前章で検討した噮状流の界面積濃度 の評価方法により算出した. 予測値に着目すると, $R e_{\mathrm{f}}=1050$ の条件では, 式(12)の液滴発生基準により, テスト管入口近傍において夜滴が発生していないが, 軸方向の圧力損失に起因して, 助走距離の増加に伴い 気相の速度が上昇することで, ある位置から液滴が発 生していることがわかる. 液相レイノルズ数が高い条 件では, テスト管入口近傍から液滴が即座に発生し, 全界面積濃度が顕著に増加することがわかる．また， 液滴の発生はテスト管入口近傍に集中しており，その 後助走距離の増加とともに緩やかに増加する傾向を示 している.

図 6 と図 7に, 全界面積濃度に対する液膜界面積濃 度の寄与率 $\eta\left(\equiv\left\langle a_{\text {i.film }}\right\rangle /\left\langle a_{\text {i.total }}\right\rangle\right)$ の, 気液レイノルズ数 への依存性を示す.気液レイノルズ数が低い条件 $\left(R e_{\mathrm{g}}=31800, R e_{\mathrm{F}}=1050\right)$ では, 液滴の発生量が少ない ため, 液膜界面積濃度の寄与率 $\eta$ は, 1 に近い值を示 している. 気液レイノルズ数の増加に伴って, $\eta$ は 徐々に減少するが，本実験における最大の気液レイノ ルズ数条件（Re $e_{\mathrm{g}}=98300, R e_{\mathrm{F}}=9430 ）$ においても， $\eta$ は 0.4 以上の高い比率を示している. このことは, 幅広 い流動条件において, 液膜が環状流の界面輸送項の重

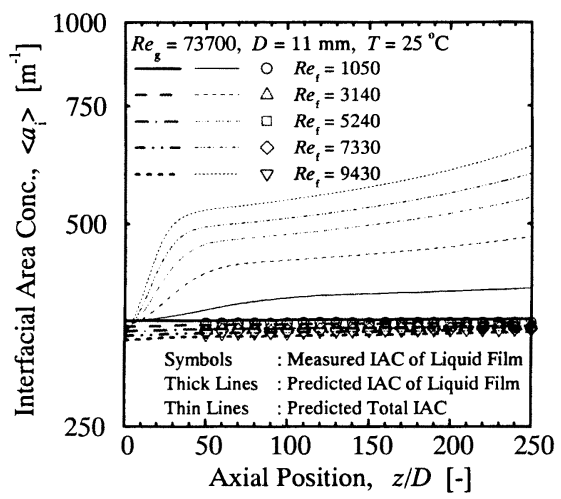

Fig. 5 Axial development of IAC of liquid film and droplet $\left(\operatorname{Re}_{\mathrm{g}}=73700\right)$ 


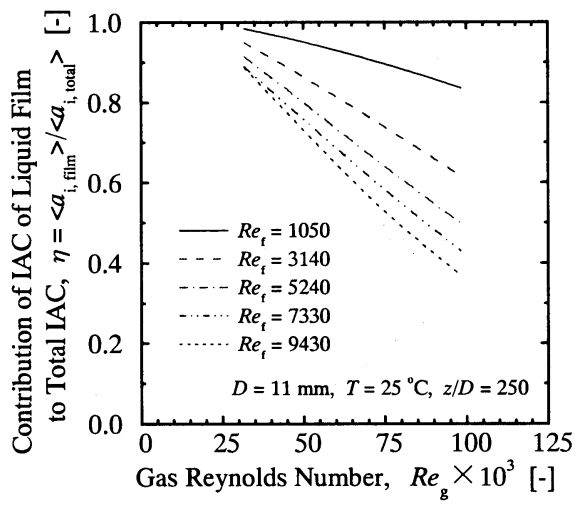

Fig. 6 Contribution of IAC of liquid film to total IAC (effect of gas Reynolds number)

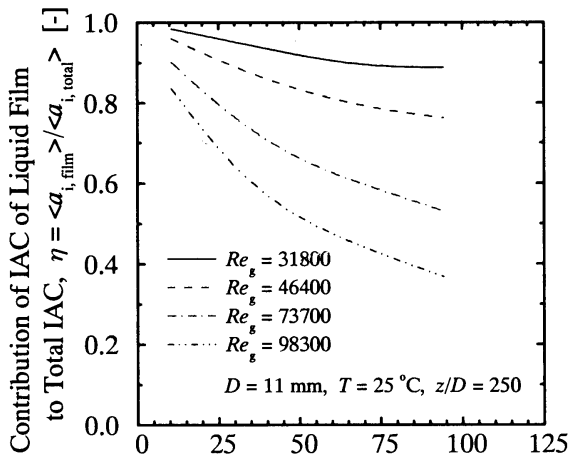

Liquid Reynolds Number, $R e_{\mathrm{f}} \times 10^{2}[-]$

Fig. 7 Contribution of IAC of liquid film to total IAC (effect of liquid Reynolds number)

要な要素となることを示している.

$3 \cdot 3$ 液膜の局所界面稍沙度 次に, LFDによる 液膜界面変位の計測結果を用いて, 液膜の局所界面積 濃度を評価する．図 8 に示すような，管断面の任意位 置に液膜の界面が存在する体系を考え, 液膜界面の管 断面 $x$ 方向の位置を $x_{0}$ とする.

$x=x_{0}$

ここで, 管断面位置 $\gamma$ 近傍の微小空間領域 $\Delta x$ を次式で 定義する.

$\gamma-\frac{\Delta x}{2} \leq x \leq \gamma+\frac{\Delta x}{2}$

空間領域 $\Delta x$ 内における瞬時の平均界面積濃度 $a_{\mathrm{i} \text { fim }}$ は 次式となる.

$a_{\mathrm{i} \text {,ilim }}=\frac{1}{\Delta x}$, for $\left|\gamma-x_{0}\right|<\frac{\Delta x}{2}$

$a_{\mathrm{iffilm}}=0, \quad$ for $\left|\gamma-x_{0}\right|>\frac{\Delta x}{2}$
ここで, 瞬時の無次元界面積濃度を次式で定義する.

$\tilde{a}_{\mathrm{i} \text {,flm }}=a_{\mathrm{i} \text {,flim }} \Delta x$

$\Delta x$ 領域内の無次元界面積濃度の時間平均値は,

$\overline{\tilde{a}}_{\text {i.film }}=\frac{1}{\Delta t} \int \tilde{a}_{\text {i.film }} d t$

となる．液膜厚さの時系列データより管断面各位置に おける $\overline{\tilde{a}}_{\text {iffilm }}$ を算出し, 各軸方向位置および流量条件 ごとに整理する.

図 9 に, 助走距離 $z / D=250$, 気相レイノルズ数 $R e_{\mathrm{g}}$ $=73700$ における無次元液膜界面積濃度の管断面分布 を示す.ここで横軸は管断面中心からの距離を示し, $r / R=1$ は管壁の位置に対応する. 図に示すように, 界 面積濃度の管断面分布は，流動条件によって鋭敏に変 化する. 液相レイノルズ数の低い $R e_{\mathrm{f}}=1050$ において 界面積濃度の断面分布は，壁面近傍に鋭いピークを有 する形状となっている. 液相レイノルズ数が増加する と, そのピークが徐々に鈍化し，管中心方向に長いす そ野を持つ分布形状へと移行する.これは液流量の増 加により界面の波立ちが激しくなるためである.

図 10 は, 気相レイノルズ数 $R e_{\mathrm{g}}=98300$, 液相レイ ノルズ数 $R e_{\mathrm{f}}=9430$ における無次元液膜界面積濃度の 管断面分布を助走距離に対して整理した結果である. 助走距離の増加に伴い分布のピークが管中心から管壁 側へと徐々に移動していく．これは，助走距離の増加 に伴って液膜界面のせん断力が增加することで, 液滴 飛散量が増加し，また液膜の厚さと波高が減少するた めである.

以上，本研究では，環状流における一次元界面積濃 度と液膜の局所界面積濃度を実験的, 解析的に評価し た. 最終的に信頼性の高い界面積濃度輸送方程式を開

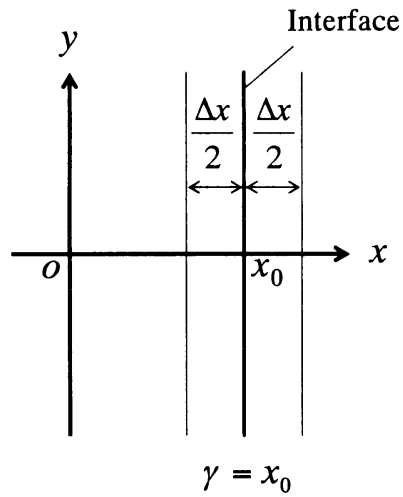

Fig. 8 Definition of local interfacial area concentration in tube cross section 


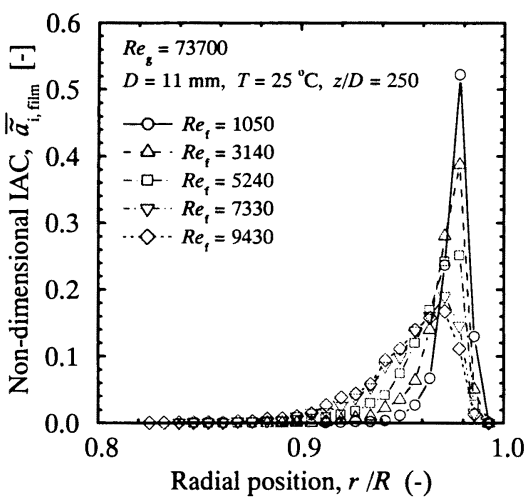

Fig. 9 Effect of liquid Reynolds number on Nondimensional local IAC distribution $\left(R e_{\mathrm{o}}=73700\right)$

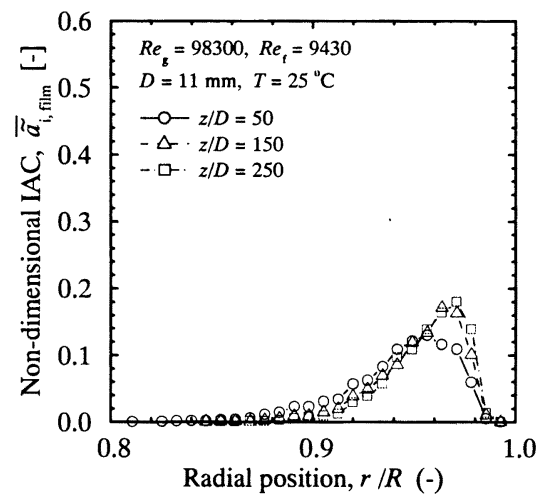

Fig. 10 Effect of entry length on Non-dimensional local IAC distribution $\left(R e_{\mathrm{g}}=98300, R e_{\mathrm{f}}=9430\right)$

発するためには, 液膜と飛散液滴の界面積濃度に関す るデータベースを拡充整備していく必要があり,この 分野を対象にした実験的研究の進展が今後期待される.

\section{4. 䊅 論}

本研究では，環状流域を対象にした界面積濃度輸送 方程式の開発を最終目的とし，その第一段階として, 垂直管上昇環状流における液膜の一次元平均界面積濃 度と管断面界面積濃度分布の管軸方向発達特性を実験 的に整理した. また，既存のドリフトフラックスモデ ルおよび液滴径と液滴飛散量に関する相関式を用いた 環状流界面積濃度の評価方法を検討し, 液膜界面積濃 度の計測結果との比較からその適用性を評価するとと もに，環状流の全界面積濃度に対する液膜界面積濃度 の奇与率を評価した. 得られた結果は以下のようにま とめられる.

（1）環状流の液膜界面積濃度は，管軸方向の発達に伴 って徐々に増加する．その増加率は，本実験の範
囲において最大で3\%であった.

(2) 既存のドリフトフラックスモデルと飛散液滴に関 する相関式を用いて，環状流における液膜界面積 濃度の軸方向変化を予測し, 実測値と比較した結 果, 両者の偏差は本実験の範囲において $2.5 \%$ 以内 であった.

(3) 全界面積濃度に対する液膜界面積濃度の奇与率は, 気液レイノルズ数の増加に伴って, 徐々に減少す ることを解析的に示した. 本実験における最小の 気液レイノルズ数条件 $\left(R e_{\mathrm{g}}=31800, R e_{\mathrm{f}}=1050\right)$ では, 液滴発生量が少ないため, 液膜界面積濃度の寄与 率は1に近い值を示した. 一方, 最大の気液レイ ノルズ数条件 $\left(R e_{\mathrm{g}}=98300, R e_{\mathrm{f}}=9430\right)$ においても, その寄与率は 0.4 以上の高い比率を示した. した がって, 広範な流動条件において, 液膜が環状流 の界面輸送項の重要な要素になると言える.

（4）液膜界面積濃度の管断面分布を，LFDによる液膜 界面変位の計測結果を用いて実験的に整理した. 液相レイノルズ数の低い条件において, 液膜界面 積濃度の分布形状は，壁面近傍に鋭いピークを有 する. また, 液相レイノルズ数が増加すると, 界 面の波立ちが激しくなることで，その分布のピー クが徐々に鈍化し，管中心方向に長いすそ野を持 つ分布形状へと移行することが確認された.

本研究の費用の一部は日本学術振興会科学研究費補 助金（研究課題番号 16760653 および 17560744）によ るものである. ここに記して感謝の意を表す.

\section{考文献}

(1) Kocamustafaogullari, G. and Ishii, M., Foundation of the Intefacial Area Transport Equation and its Cosure Relations, International. Journal of Heat and Mass Transfer, Vol. 38 (1995), pp. 481493.

(2) Wu, Q., et al., One-group Interfacial Area Transport in Vetical Bubbly Flow, International Joumal of Heat and Mass Transfer, Vol. 41 (1998), pp. 1103-1112.

(3) Hibiki, T. and Ishii, M., One-grope Interfacial Area Transport of Bubbly Flows in Vertical Round Tubes, International Journal of Heat and Mass Transfer, Vol. 43 (2000), pp. 2711-2726.

(4) Hibiki, T. and Ishii, M., Two-grope Inteffacial Area Transport Equations at Bubbly-ta-shg Flow Transition, Nuclear Engineering and Design, Vol. 202 (2000), pp. 39-76.

(5) Hibiki, T., et al, Interfacial Area Transport of Bubbly Flow in a Small Diameter Pipe, Joumal of Nuclear Science and Technology, Vol. 38 (2001), pp. 614-620. 
(6) Fu, X. Y. and Ishii, M., Two-group Interfacial Area Transport in Vertical Air-water Flow: I Mechanistic Model, Nuclear Engineering and Design, Vol. 219-2(2003), pp. 143-168.

(7) Ishii, M., One-dimensional Drift Fhx Model and Constitutive Equations for Relative Motion Between Phases in Various Twophase Flow Regimes, Argonne National Laboratory Report, ANL 77-47 (1977).

(8) Kataoka, et al, Generation and Size Distribution of Droplet in Annular Twophase Flow, Journal of Fluids Science, Vol. 105 (1983), pp. 230-238.

(9) Ishii, M. and Mishima, K., Droplet Entraimment Correlation in Annular Twophase Fow, International Joumal of Heat and Mass Transfer, Vol. 32-10 (1989), pp. 1835-1846.

(10) Ishii, M. and Grolmes, M. A., Inception Criteria for Droplet Entraimment in Twophase Conaument Film Fow, $A I C h E$ Journal, Vol. 21-2 (1975), pp. 308-318.

(11) Ishii, M., One-dimensional Drift Flux Modeling: OneDimensional Drift Velocity of Dispersed Flow in Confined Channel, Argonne National Laboratory Report, ANL-76-49 (1976).

(12) Alia, P., et al., Liquid Volume Fraction in Adiabatic Two-phase Vertical Upflow-round Conduit, CISE Report, Vol. 105 (1965).

(13) Gravarolo, L, et al., A Device for the Measurement of Shear Stress on the Wall of a Concuit: It Application in the Mean Density Determination in Twophase Flow. Shear Stress Data in Twophase Adiabatic Vertical Flow, CISE Report, Vol. 82 (1964).

(14) Kataoka, I. and Ishii, M., Mechanism and Comelation of Droplet Entrainment and Deposition in Annular Two-phase Flow, Argonne National Laboratory Report, ANL-82-44 (1982).
(15) Hazuku, T., et al., Measurement of Interfacial Structure on Liquid Film in Annular Flow Using Laser Focus Displacement Meter: 1st Report, Measurement Accuracy and Axial Development of Liquid Film, Transactions of the Japan Society of Mechanical Engineers, Series B, Vol. 71, No. 705 (2005), pp. 1265-1271.

(16) Hazuku, T., et al., Measurement of Interfacial Structure on Liquid Film in Annular Flow Using Laser Focus Displacement Meter: 2nd Report, Disturbance Wave Frequency and Local Minimum Film Thickness, Transactions of the Japan Society of Mechanical Engineers, Series B, Vol. 71, No. 705 (2005), pp. 1272-1277.

(17) Takamasa, T. and Hazuku, T., Measuring a Film Flowing Down a Vertical Wall Using Laser Focus Displacement Meters: 1st Report, Measuring Principle and Film Thickness, Transactions of the Japan Society of Mechanical Engineers, Series B, Vol. 64, No. 617 (1998), pp. 128-135.

(18) Hazuku, T., et al., Measurement of Interfacial Displacement of a Liquid Film in Microchannels Using Laser Focus Displacement Meter, Transactions of the Japan Society of Mechanical Engineers, Series B, Vol. 70, No. 694 (2004), pp. 1481-1488.

(19) Takamasa, T. and Kobayashi, K, Measuring a Film Flowing Down a Vertical Wall Using Laser Focus Displacement Meters: 3rd Report, Measuring Principle for a Film on Tube Inner Wall and the Interfacial Waves, Transactions of the Japan Society of Mechanical Engineers, Series B, Vol. 64, No. 628(1998), pp. 4023-4030. 